Progressive Physics Journal
Volume 2, Nomor 1, Juni 2021
ISSN 2722-7707 (online)
http://jurnal.fmipa.unmul.ac.id/index.php/ppj/index

\title{
Rancang Bangun Sistem Monitoring Suhu dan Salinitas pada Air Laut
}

\author{
Azizah Bella ${ }^{1, *)}$, Devina R.P.S.Putri ${ }^{1}$, I Mandang ${ }^{1}$ \\ 1) Prodi Fisika, FMIPA Universitas Mulawarman \\ JIn. Barong Tongkok, Gn. Kelua, Kec. Samarinda Ulu, kota Samarinda 75242 Kalimantan Timur, \\ Indonesia \\ *E-mail : zahizah1214@gmail.com
}

\begin{abstract}
Knowing the condition of the waters is very important for the sustainability of aquatic ecosystems. The condition of the waters so as not to have a bad impact on aquatic ecosystems can be known through temperature and salinity parameters. Seawater temperature is the distribution of heat in the ocean caused by the movement of water and other factors. The salinity of seawater is the level of saltiness or the level of salt dissolved in seawater. Temperature can be measured using a thermometer and salinity is measured using a refractometer. However, using these tools requires time, effort, cost, and manual data retrieval processes. Therefore, this research aims to make a temperature and salinity measuring instrument and determine the relationship between Voltage and salinity in the seawater. This research used the method of measuring electrical conductivity (DHL) to determine a change in magnitude. The temperature and salinity design consisted of an Arduino Uno, a YL-38 Module, and copper as an electrode, and a DS18B20 Temperature Sensor. the result of this research shows that has been done, the average error presentation of salinity is $0.00732 \%$ and temperature is $0.044 \%$. Through this research, salinity and the temperature instrument produced using electrodes made of copper and DS18B20 which operate at a Voltage of 4,8 Volts. The obtained a linear graph between stress and salinity. The relationship between voltage and salinity is directly proportional, the higher the salinity of seawater, the greater the output voltage.
\end{abstract}

Key words: Salinity, Temperature, Voltage

\section{PENDAHULUAN}

Menurunnya kualitas perairan menjadi perhatian utama dalam permasalahan lingkungan pada saat ini. Permasalahan ini disebabkan oleh masuknya pencemaran yang berasal dari berbagai kegiatan manusia seperti sampah pemukiman, industri, pertambangan, dan pestisida. Kondisi perairan dapat dilihat dari beberapa nilai konsentrasi dari parameter kualitas air, yaitu pengamatan suhu, kekeruhan, warna, intensitas cahaya, total dissolved solid (TDS), daya hantar listrik (DHL), kadar garam (salinitas), bau, rasa, kadar clorida, dan derajat keasaman (pH) [1]. Kadar garam (salinitas) dan suhu menjadi salah satu hal yang penting diketahui agar tidak berdampak buruk terhadap keberlangsungan ekosistem air.

Salinitas dan suhu dapat diukur dengan menggunakan alat refractometer dan termometer air raksa. Refractometer merupakan alat pengukur salinitas dengan mengukur indeks pembiasan pada cairan yang digunakan untuk mengukur kadar garam. Termometer air raksa dapat bekerja 
ketika volume zat cair (air raksa) berubah ketika dipanaskan atau didinginkan. Namun penggunaan alat tersebut membutuhkan waktu, tenaga, biaya dan memerlukan proses pengambilan data sampel air laut dengan pipet sehingga terbilang manual dalam pengimputan data. Berdasarkan penelitian yang dilakukan oleh [2], bahwa pengukuran salinitas uSmumnya menggunakan alat ukur manual berupa refractometer dan salinitymeter. Pengukuran semacam ini hanya bisa dilakukan secara berkala dengan melibatkan banyak tenaga setiap titik pengukuran. Sementara itu, penelitian yang dilakukan oleh [3], yaitu memperbaharui jenis mikrokontroler yang sudah pernah digunakan sebelumnya.

Oleh karena itu, atas dasar pertimbanagan dan alasan tersebut, maka dilakukan penelitian ini untuk membuat alat guna mengukur nilai salinitas dan suhu pada air laut. Pengukuran salinitas dengan menggunakan metode konduktivitas, yaitu dengan memanfaatkan daya hantar listrik pada air laut dan mikrokontroler ATmega328 sebagai pengolah data dan analog digital converter (ADC) yang digunakan untuk mengkonveksikan sinyal analog ke digital dari beberapa sensor yang digunakan untuk memberikan informasi dari fenomena air laut. Alat ukur yang dibuat portable sehingga dapat digunakan untuk penelitian lebih lanjut.

\section{TINJAUAN PUSTAKA}

Air laut adalah suatu medium kehidupan karena menyediakan seluruh yang dibutuhkan untuk pertumbuhan dan pemeliharaan tumbuhan dan hewan. Menurut teori, zat garam yang terdapat dalam air laut berasal dari dasar laut melalui proses outgassing, yakni rembesan dari kulit bumi di dasar laut yang berbentuk gas ke permukaan dasar laut. Sebagaian besar komponen air laut adalah garam-garam yang beraneka ragam. Jumlah masing-masing garam yang terkandung di dalam air laut berbeda-beda. Bahkan, komposisi garam antara air laut di daerah satu dengan daerah lainnya pun berbeda. Garam-garaman utama yang terdapat dalam air laut adalah klorida (55\%), natrium (31\%), sulfat ( $8 \%)$, magnesium (4\%), kalsium (1\%), potasium (1 $\%)$, dan sisanya (kurang dari $1 \%$ ) terdiri dari biokarbonat, bromida, asam borak, strontium, dan florida [2].

Ciri paling khas pada air laut adalah rasanya yang asin. Hal tersebut disebabkan karena di dalam air laut terlarut bermacam-macam garam, utamanya adalah garam natrium klorida ( $\mathrm{NaCl})$. Air laut mengandung 3,5 \% garam-garaman, gas-gas terlarut, bahan-bahan organik, dan partikelpartikel tak terlarut. Keberadaan garam-garaman memengaruhi sifat fisis air laut (seperti: densitas, kompresibilitas, titik beku, dan temperatur dimana densitas menjadi maksimum) beberapa tingkat, tetapi tidak menentukannya. Beberapa sifat (viskositas, daya serap cahaya) tidak terpengaruh secara secara signifikan oleh salinitas. Dua sifat yang sangat ditentukan oleh jumlah garam di laut (salinitas) adalah daya hantar listrik (konduktivitas) dan tekanan osmosis [2].

Temperatur merupakan ukuran energi gerakan molekul. Suhu bervariasi secara horizontal sesuai dengan garis lintang dan secara vertikal sesuai dengan kedalaman. Suhu merupakan faktor penting dalam mengatur proses kehidupan dan penyebaran organisme. Temperatur laut adalah besaran fisis yang mempunyai rentang antara $35{ }^{\circ} \mathrm{C}$ dan $-2{ }^{\circ} \mathrm{C}$. Air laut bila ditinjau dari distribusi sifat-sifat fisis atau kimiawinya, secara umum adalah berlapis (stratified). Distribusi sifat-sifat fisis maupun kimiawi air laut umumnya zonal, dalam arti tidak banyak perubahan dalam sifat-sifat air pada arah barat-timur [3].

Faktor lain yang juga mempengaruhi suhu perairan adalah batimetri dan pegunungan di daratan. Secara vertikal, profil suhu di suatu perairan dalam terbagi dalam tiga lapis utama. Pertama, lapisan permukaan yang tercampur sempurna (mixed layer). Lapisan ini hangat dan memiliki gradien suhu dengan kedalaman yang kecil. Kedua, lapisan termoklin (thermocling 
layer) yakni lapisan dengan penurunan suhu yang mencolok atau lapisan yang memiliki gradien suhu yang besar. Gradien suhu pada lapisan ini sekitar $0,1{ }^{\circ} \mathrm{C}$ per meter. Terakhir, lapisan dalam (deep layer) yang memiliki suhu yang rendah tetapi relatif konstan pada $4{ }^{\circ} \mathrm{C}$ [4]. Gambar 1 merupakan profil vertikal suhu air laut.

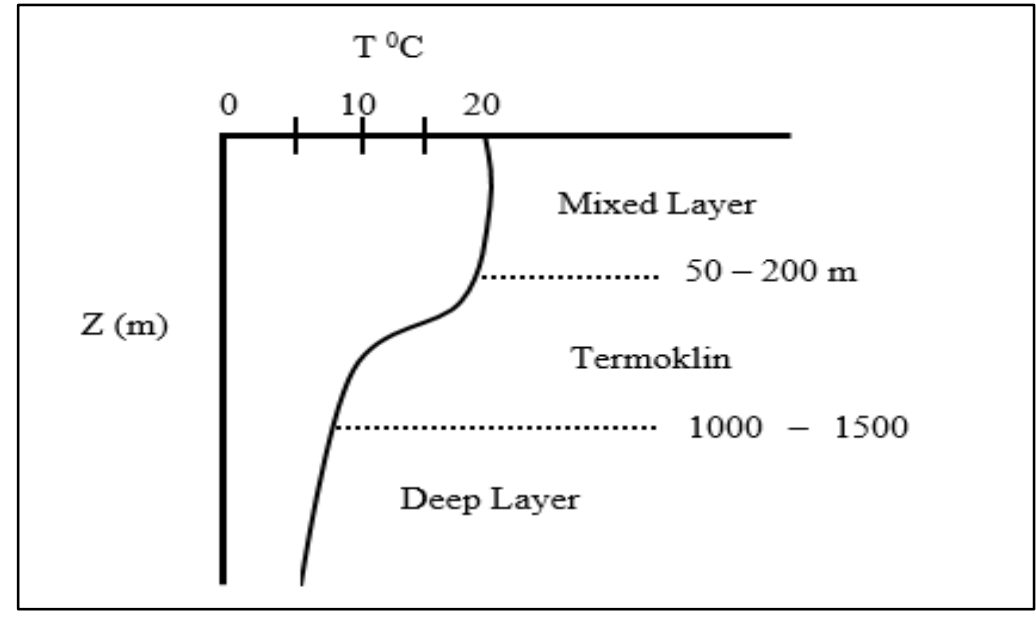

Gambar 1. Profil Vertikal Suhu Air Laut [3]

Air laut memiliki kadar garam karena bumi dipenuhi dengan garam mineral yang terdapat di dalam batu-batuan dan tanah. Contohnya Natrium, Kalium, Kalsium, dll. Apabila air sungai mengalir ke lautan, air tersebut membawa garam. Ombak laut yang memukul pantai juga dapat menghasilkan garam yang terdapat pada batu-batuan. Semakin lama air laut menjadi asin karena banyak mengandung garam [5].

Menurut Suryono salinitas berasal dari kata salinus artinya garam, didefinisikan sebagai tingkat keasinan atau kadar garam yang terlarut dalam air. Satuan salinitas dinyatakan dalam $\%$ (part per thousand) [6]. Berdasarkan tingkat salinitasnya perairan dibedakan menjadi beberapa jenis seperti ditunjukan pada Tabel 1.

Tabel 1. Perbedaan Salinitas Perairan [6]

\begin{tabular}{ll}
\hline Sebutan/Istilah & Salinitas (ppt) \\
\hline Air Tawar & \\
Fresh Water & $<0.5$ \\
Oligahaline & $0.5-3.0$ \\
Air Payau & \\
Mesohaline & $3.0-16.0$ \\
Polyhaline & $16.0-30.0$ \\
Air Laut & \\
Marine & $30.0-40.0$ \\
\hline
\end{tabular}

Mikrokontroler di sebut juga komputer kecil ("special purpuse computers") di dalam suatu IC yang berisi CPU, memori, timer, saluran komunikasi serial dan paralel, port input/ouput, ADC. Mikrokontroler digunakan untuk suatu tugas dan menjalankan suatu program. Mikrokontroler sering disebut sebagai mikrokomputer atau embedded system. Mikrokontroler dipandang sebagai suatu sistem yang terdiri atas input, program dan output. Mikrokontroler dapat diatur oleh sebuah program. Proses untuk memasukkan program ke dalam mikrokotroler disebut dengn download dan alat yang digunakan disebut dengan downloader, seperti sistem komputer 
nilai tambah sistem mikrokontroler dapat dilipatgandakan melalui program. Mikrokontroler diproduksi dalam bentuk rangkaian terpadu (IC) [7].

Sensor suhu DS18B20 berfungsi untuk merubah besaran panas yang di tangkap menjadi besaran tegangan. Jenis sensor suhu yang digunakan dalam sistem ini adalah IC DS18B20, sensor ini memiliki presisi tinggi. Sensor ini sangat sederhana denga hanya memiliki 3 buah kaki. Kaki pertama IC DS18B20 dihubung ke sumber daya, kaki kedua sebagai output dan kaki ketiga dihubungkan ke ground [8].

Pengukuran salinitas umumnya menggunakan alat ukur manual berupa Refractometer dan salinitymeter. Pengukuran semacam ini hanya bisa dilakukan secara berkala dengan melibatkan banyak tenaga untuk setiap titik pengukuran. Metode lain pengukuran salinitas, yaitu menggunakan sensor. Hasilnya berupa data digital yang dapat disimpan dalam bentuk database dan dapat diolah lebih lanjut. Namun, sensor salinitas yang tersedia di pasaran masih kurang stabil. Faktor penyebabnya berasal dari metode sensing yang digunakan, yaitu konduktivitas sehingga elektrolisis tidak dapat dihindari [6].

Sensor salinitas merupakan sensor yang dirancang berdasarkan sifat kelistrikan air. Resistansi pada air akan berkurang seiring dengan bertambahnya kadar garam. Sensor salinitas terdiri dari dua buah elektroda yang dicelupkan ke dalam air. Sensor diberi sebuah beda potensial agar terjadi aliran elektron pada rangkaian pembangun sensor. Elektroda diserikan dengan sebuah resistor variabel yang membentuk hubungan rangkaian pembagi tegangan. Tegangan keluaran sensor elektroda diukur pada terminal AB seperti yang tampak pada Gambar 2, kemudian data ini akan dikirim ke Arduino. Rangkaian dan ilustrasi sensor elektroda untuk mengukur salinitas dapat dilihat pada Gambar 2 [1].

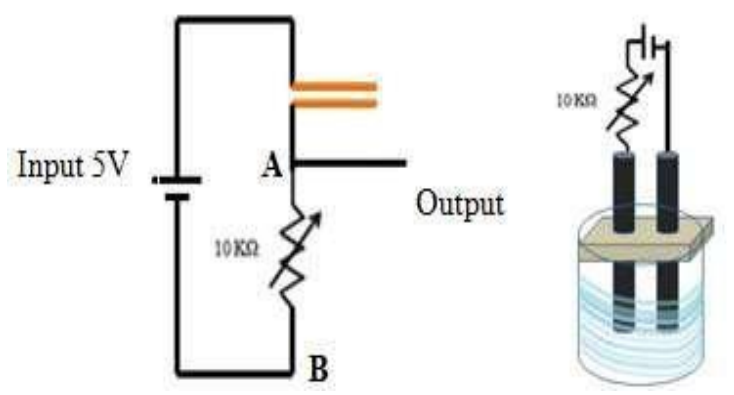

Gambar 2. Ilustrasi Rangkaian Salinitas [1]

Apabila elektroda dicelupkan kedalam air, maka rangkaian pada Gambar 2 menjadi rangkaian tertutup. Hal ini menyebabkan ion-ion dalam air akan bebas. Ion-ion pada air akan menghantarkan arus listrik sehingga tegangan pada terminal AB dapat dibaca [1].

Konduktivitas listrik adalah kemampuan suatu larutan untuk menghantarkan arus listrik. Arus listrik bergerak dengan efisien melalui air yang mempunyai kadar garam tinggi (konduktivitas elektrik tinggi), dan bergerak dengan resistansi lebih melalui air murni (konduktivitas rendah). Konduktivitas listrk juga mengindikasikan berapa banyak garam yang terlarut dalam suatu sampel [9]. Konduktivitas listrik dalam logam berkaitan dengan hukum Ohm:

[9]

$$
\begin{gathered}
I=\frac{V}{R} \\
R=\frac{L \rho}{A} \\
\sigma=\frac{1}{\rho}
\end{gathered}
$$




\section{METODE PENELITIAN}

Penelitian ini dilakukan pada bulan Maret 2020 hingga Februari 2021 di Laboratorium Elektronika dan Instrumentasi, Jurusan Fisika, Fakultas Matematika dan Ilmu Pengetahuan Alam, Universitas Mulawarman, Samarinda, Kalimantan Timur dan di Jembatan Nelayan, Berbas Pantai, Bontang Selatan, Kalimantan Timur.

\section{Alat dan Bahan}

Dalam penelitian ini, adapun alat dan bahan yang digunakan antara lain, yaitu kabel tembaga berfungsi sebagai elektroda untuk menangkap beda potensial listrik pada air laut. Modul YL-38 sebagai potensiometer. DS18B20 berfungsi sebagai sensor pada suhu air laut. Resistor 4,7k $\Omega$ berfungsi sebagai hambatan dalam rangkaian elektronika. Arduino Uno ATMega 328 ULN 2003 berfungsi sebagai otak dan pengolahan data tegangan yang didapat dari rangkaia

n. Laptop digunakan untuk menampilkan dan pengolahan data. Kabel penghubung, solder, dan timah digunakan untuk menghubungkan antara komponen satu dengan komponen lainnya. Refractometer dan termometer digital sebagai pembanding alat yang di buat. Avometer digunakan untuk mengukur arus, tegangan dan hambatan pada rangkaian. Dalam penelitian ini digunakan bahan, yaitu air dan garam sebagai bahan sampel pengujian rancang bangun salinitas, dan air laut sebagai bahan penelitian.

\section{Prosedur dan Proses Penelitian}

Prosedur dalam penelitian ini dilakukan dalam 3 tahap yaitu: tahap pertama diawali dengan studi literatur, tahap kedua dilakukan desain dan perancangan alat dengan proses persiapan alat dan bahan, dan tahap ketiga pada penelitian ini adalah proses penelitian dilakukan dengan pengujian alat dan proses pengambilan data.

Proses yang dilakukan dalam penelitian ini dibagi atas beberapa tahap, yaitu:

1. Tahap studi literatur, tahap studi literatur dilakukan pengumpulan literatur tentang karakteristik kualitas air laut;

2. Tahap desain dan perancangan, rancang bangun alat salinitas dan suhu dibagi menjadi dua bagian yaitu merancang perangkat keras (hardware) dan perangkat lunak (software). Perangkat keras terdiri dari Arduino Uno, elektroda, resistor dan sensor suhu. Sedangkan perangkat lunak menggunakan aplikasi Arduino yang berfungsi sebagai otak dalam rancang bangun sensor salinitas dan suhu. Gambaran secara umum cara kerja rancang bangun sensor salinitas dan suhu berbasis Arduino ditunjukkan pada diagram balok Gambar 3;

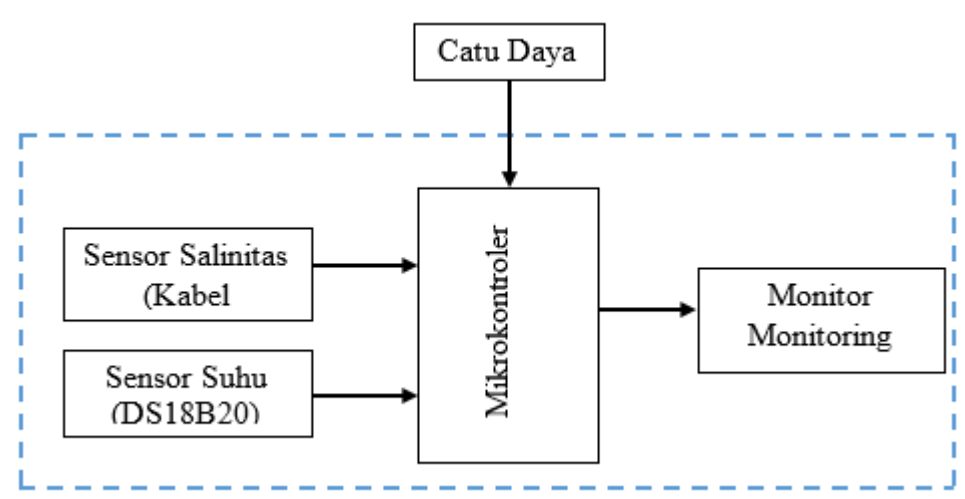

Gambar 3. Diagram Blok Sensor Salinitas dan Suhu

3. Tahap pengujian dan pengambilan data, pada proses pengujian dilakukan di Laboratorium Elektronika dan Instrumentasi dengan menggunakan air campuran garam. Setelah didapatkan 
perubahan tegangan yang diinginkan dari pengujian dilanjutkan dengan pengambilan data. Pengambilan data dilakukan dengan mengukur nilai salinitas air laut di Jembatan Nelayan, Berbas Pantai, Bontang Selatan, Kalimantan Timur cara yaitu mengukur nilai salinitas dari pangkal jembatan hingga ujung jembatan dengan jarak titik ke-0 hingga titik ke-9 adalah \pm 10 meter dengan waktu pertitik 5 menit. Kemudian dilakukan pengambilan data berupa kadar garam atau salinitas, tegangan dan suhu;

4. Tahap pengolahan data, pada tahap ini data berupa tegangan untuk alat salinitas dan mengkonversi ke bentuk nilai salinitas begitu juga dengan alat suhu dan kemudian membandingkan nilai yang telah dikonversi dengan alat pembanding salinometer; dan

5. Dilakukan analisis data penelitian.

\section{Analisis Data}

Pada penelitian ini, dilakukan pengujian rangkaian salinitas dan sensor suhu DS18B20 yang kemudian dibandingkan dengan alat kalibrator standar. Pengujian salinitas dilakukan untuk mengetahui tegangan keluaran (output) nilai salinitas pada kalibrator. Kemudian, digunakan persamaan sebagai berikut untuk mendapatklan nilai salinitas:

$$
y=a x \pm b
$$

nilai salinitas yang dibuat (AUD) dan nilai salinitas alat standar (AUS) dicari nilai ketepatan rancang bangun salinitas menggunakan persamaan sebagai berikut:

$$
\text { presentase kesalahan }=\left|\frac{\text { Salinitas AUD-salinitas AUS }}{\text { salinitas } A U D}\right| \times 100 \%
$$

nilai sensor suhu DS18B20 yang dibuat (AUD) dan nilai termometer alat standar (AUS) dicari nilai ketepatan rancang bangun sensor suhu DS18B20 menggunakan persamaan sebagai berikut:

$$
\text { presentase kesalahan }=\left|\frac{\text { Suhu AUD-suhu AUS }}{\text { suhu } A U D}\right| \times 100 \%
$$

\section{HASIL}

Rancang bangun alat salinitas dan suhu dibagi menjadi dua bagian, yaitu merancang perangkat keras (hardware) dan perangkat lunak (software). Perangkat keras terdiri dari Arduino Uno, elektroda, resistor dan sensor suhu. Sedangkan perangkat lunak menggunakan aplikasi arduino yang berfungsi sebagai otak dalam rancang bangun sensor salinitas dan suhu. Adapun proses pembuatan hardware atau perangkat keras pada penelitian rancang bangun salinitas dan suhu yang telah dilakukan sebagai berikut. 


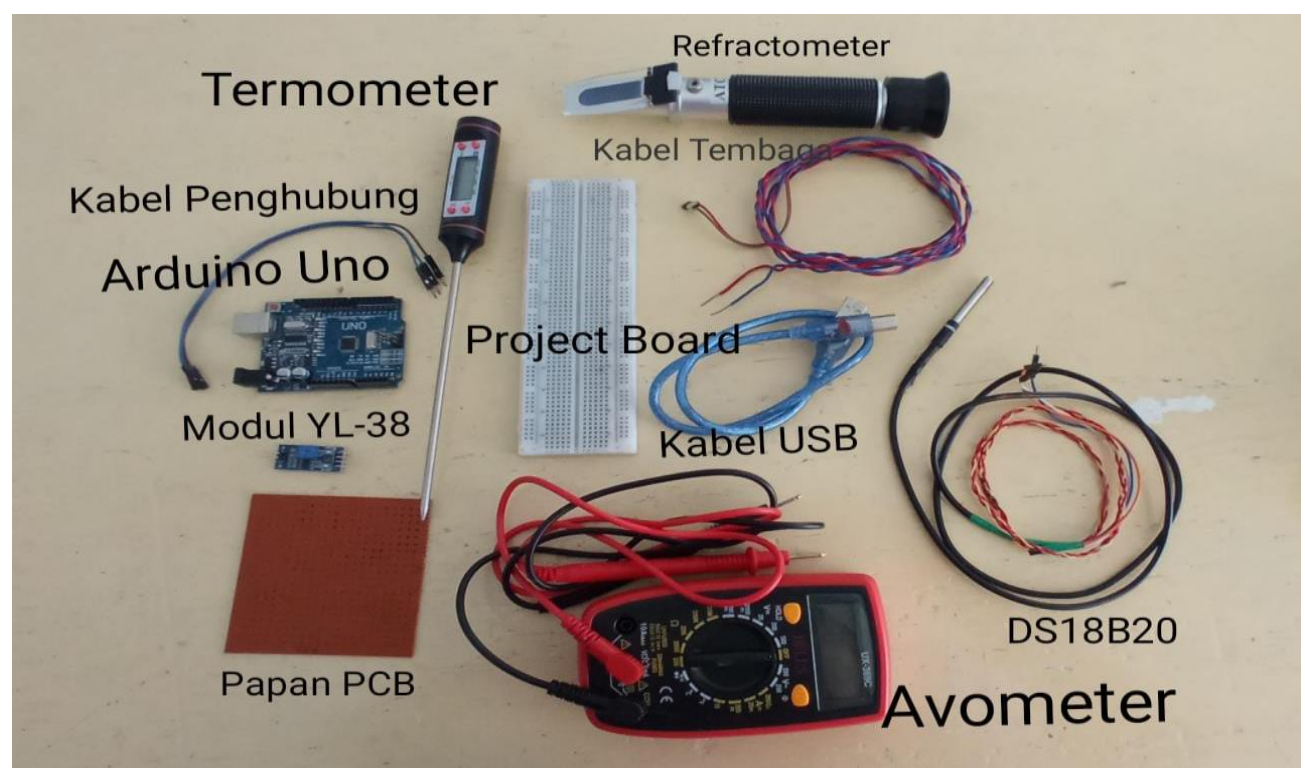

Gambar 4. Alat dan Bahan yang Digunakan

Pada Gambar 4 menunjukkan alat dan bahan yang digunakan dalam penelitian. Dalam penelitian ini, adapun alat dan bahan yang digunakan antara lain, yaitu kabel tembaga, Modul YL-38, sensor DS18B20, resistor 4,7 k , Arduino Uno ATMega328. Arduino Uno ATMega328 digunakan pada penelitian ini karena dalam penggunaannya lebih mudah, dapat dikoneksikan melalui USB atau dengan catu daya eksternal. Mempunyai tegangan pengoperasian 5 Volt, dengan batas tegangan input 6 - 20 Volt. Menyediakan 14 pin I/O digital dan 6 pin Input Analog. Memiliki EEPROM (Electrical Erasable Programmable Read Only Memory) sebesar 1 KB sebagai pengimpanan data semi permanen sehingga dapat menyimpan data meskipun catu daya diputuskan atau dimatikan. Laptop digunakan untuk menampilkan dan pengolahan data. Kabel penghubung, solder, dan timah. Refractometer, termometer,dan avometer untuk mengukur kuat arus, tegangan, dan hambatan pada rangkaian rancang bangun.

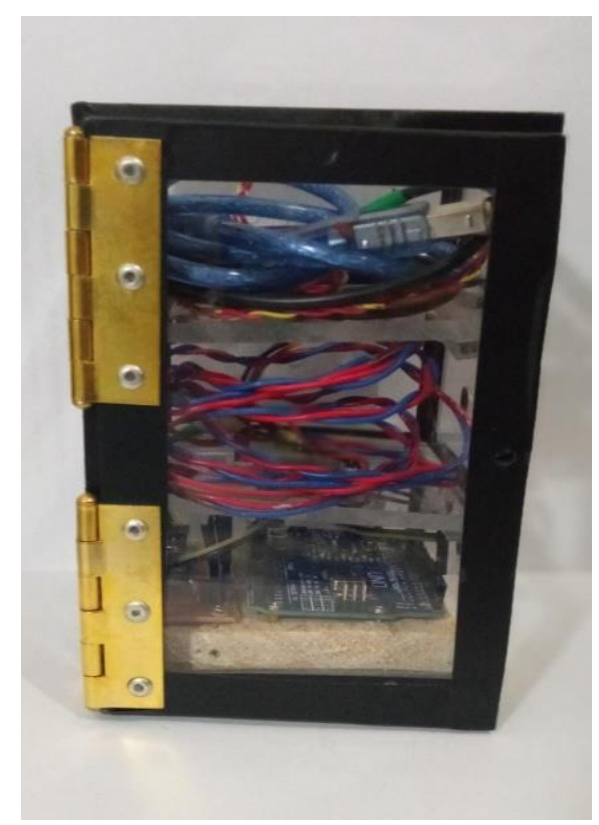

Gambar 5. Box Rancang Bangun Salinitas dan Suhu 
Rangkaian elektronika pembangun alat rancang bangun di tempatkan dalam box rangkaian yang dapat dilihat pada Gambar 5. Box rangkaian berisis semua komponen yang telah dirangkai. Secara keseluruhan box ini terdiri dari pendeteksi salinitas, temperatur/suhu, kabel USB dan tempat rangkaian rancang bangun. Bagian pendeteksi akan mengukur salinitas dan suhu dengan cara dicelupkan ke dalam air laut.

Perancangan perangkat lunak berfungsi sebagai pemberi instruksi atau perintah menjalankan program. Perintah yang dilakukan adalah untuk mengambil informasi tegangan keluaran dan suhu pada air laut. Informasi ini kemudian diolah pada mikrokontroler Arduino dengan bahasa C. Tahap awal pada program adalah memberi inisialisasi setiap variabel dan pin Arduino yang digunakan dalam proses pengukuran. Setelah itu perintah untuk membaca data yang di dapat. Data yang diterima kemudian diolah di mikrokontroler dan ditampilkan pada serial monitor pada Arduino.

Pengujian sistem rangkaian salinitas dilakukan untuk mengetahui apakah rancangan yang dibuat mampu memberikan respon terhadap setiap perubahan tingkat salinitas. Lokasi pengujian rangkaian salinitas dilakukan di Jembatan Nelayan Berbas Pantai Bontang Selatan. Pengujian ini dilakukan sepanjang jembatan dari pangkal jembatan hingga ujung jembatan, yang dimana ujung jembatan berhubungan langsung dengan laut lepas. Pengujian ini dilakukan pada Kamis, 11 Februari 2021 Pukul 14.50 WITA. Berikut hasil pengujian rangkaian salinitas yang disajikan pada Tabel 2.

Tabel 2. Data Tegangan Keluaran dan Salinitas

\begin{tabular}{ccc}
\hline No. & Tegangan Keluaran $(\mathrm{V})$ & Salinitas $(\mathbf{0} / \mathbf{0})$ \\
\hline 1. & 1.135 & 29 \\
2. & 1.140 & 29 \\
3. & 1.150 & 29.5 \\
4. & 1.155 & 30 \\
5. & 1.165 & 30 \\
6. & 1.170 & 30 \\
7. & 1.230 & 31 \\
8. & 1.240 & 31 \\
9. & 1.250 & 32 \\
10. & 1.260 & 32 \\
\hline
\end{tabular}

Tabel 2 menunjukkan pengukuran nilai dari tegangan keluaran dan nilai refractometer. Pada tabel tersebut, diketahui bahwa nilai tegangan keluaran yang di dapat akan berubah ketika nilai salinitasnya berubah. Dari Tabel 2 didapatkan grafik seperti berikut. 


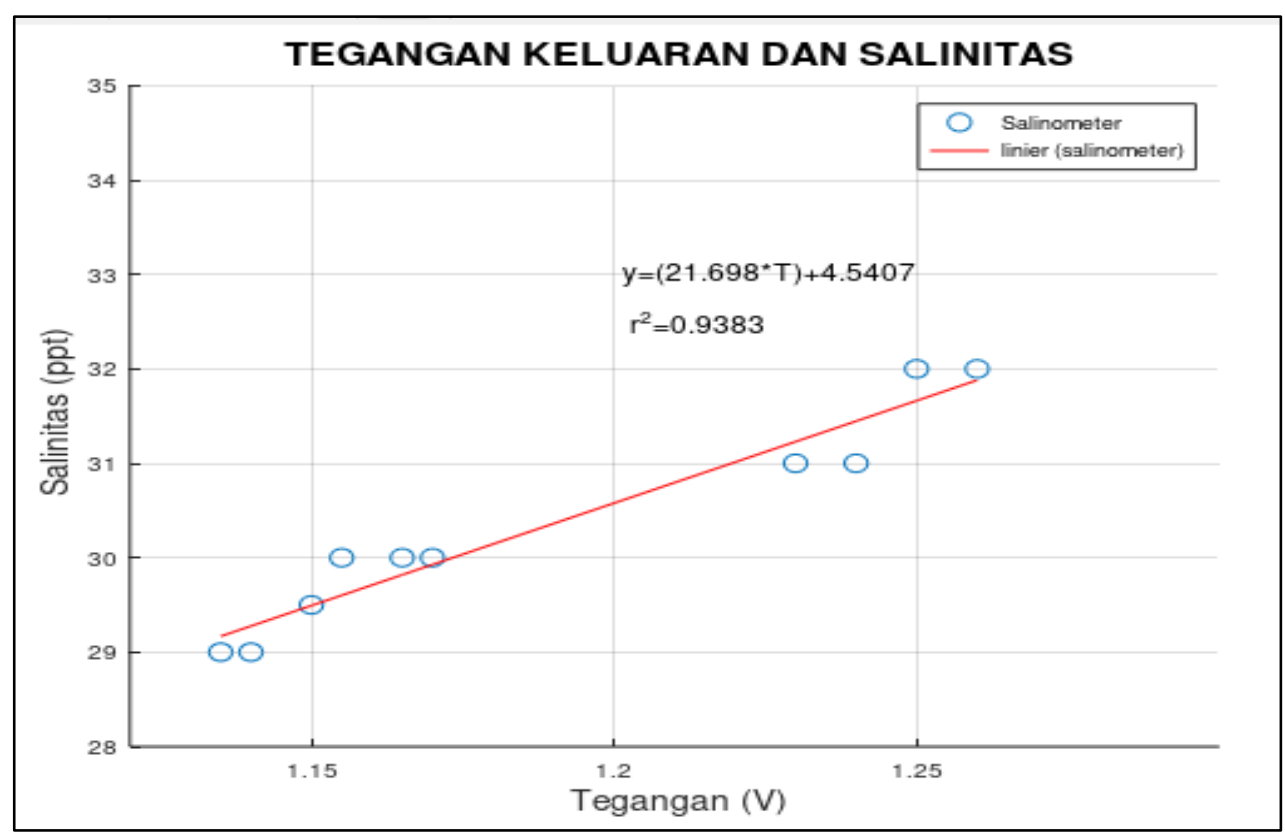

Gambar 6. Grafik Kaitan Tegangan Keluaran dan Salinitas

Gambar 6 menunjukkan kaitan antara tegangan keluaran terhadap salinitas pada pengujian rangkaian salinitas. Dari grafik tersebut diperoleh nilai regresi linier rangkaian salinitas sebesar y $=21,698 x+4,5407$. Selanjutnya, persamaan linier grafik digunakan untuk merubah nilai tegangan menjadi nilai tingkat salinitas pada Arduino Uno yang ditunjukkan oleh Tabel 3.

$$
y=a x+b
$$

Akurasi pada rancang bangun salinitas dapat diketahui melalui persamaan berikut:

$$
\text { presentase kesalahan }=\left|\frac{\text { Salinitas AUD-salinitas AUS }}{\text { salinitas } A U D}\right| \times 100 \%
$$

tingkat salinitas yang dibaca oleh sistem rancang bangun salinitas yang di buat (AUD). Nilai tingkat salinitas yang dibaca oleh sistem ini, kemudian di bandingkan dengan salinometer alat standar (AUS) yaitu refractometer. Berikut merupakan hasil pengukuran perbandingan tingkat akurasi yang dilakukan disajikan pada Tabel 3.

Tabel 3. Data Perbandingan Salinitas Rancang Bangun yang Dihasilkan dan Refractometer Alat Ukur Standar

\begin{tabular}{cccc}
\hline No. & Salinitas AUD $(\%)$ & Salinitas AUS $(\%)$ & Presentase kesalahan $(\%)$ \\
\hline 1. & 29.168 & 29 & 0.0058 \\
2. & 29.276 & 29 & 0.0095 \\
3. & 29.493 & 29.5 & 0.0002 \\
4. & 29.602 & 30 & 0.0133 \\
5. & 29.819 & 30 & 0.006 \\
6. & 29.927 & 30 & 0.0024 \\
7. & 31.229 & 31 & 0.0074 \\
8. & 31.446 & 31 & 0.0144 \\
9. & 31.663 & 32 & 0.0105 \\
10. & 31.880 & 32 & 0.0037 \\
\hline \multicolumn{4}{r}{} \\
\hline
\end{tabular}


Pengujian sistem rangkaian sensor suhu DS18B20 dilakukan untuk mengetahui apakah rancangan yang dibuat mampu memberikan respon terhadap setiap perubahan suhu air laut. Lokasi pengujian rangkaian salinitas dilakukan di Jembatan Nelayan Berbas Pantai Bontang Selatan. Pengujian ini dilakukan sepanjang jembatan dari pangkal jembatan hingga ujung jembatan, yang dimana ujung jembatan berhubungan langsung dengan laut lepas. Pengujian ini dilakukan pada Kamis, 11 Februari 2021 Pukul 14.50 WITA. Hasil pengujian rangkaian sensor suhu DS18B20 yang dibaca oleh sistem rancang bangun kemudian di bandingkan dengan termometer digital sebagai acuannya. Perbandingan tingkat akurasi yang dilakukan untuk mengetahui tingkat keakurasian pada DS18B20. Akurasi pada sensor suhu dapat diketahui melalui persamaan berikut:

$$
\text { presentase kesalahan }=\left|\frac{\text { Sensor DS18B20-Termometer }}{\text { Sensor DS18B20 }}\right| \times 100 \%
$$

Tabel 4. Data Perbandingan DS18B20 denganTermometer

\begin{tabular}{cccc}
\hline No. & DS18B20 $\left({ }^{\circ} \mathrm{C}\right)$ & Termometer $\left({ }^{\circ} \mathrm{C}\right)$ & Presentase kesalahan $\left({ }^{\circ} / 0\right)$ \\
\hline 1. & 31.31 & 33.3 & 0.063 \\
2. & 31.19 & 33.4 & 0.071 \\
3. & 31.31 & 32.8 & 0.048 \\
4. & 31.19 & 33.1 & 0.061 \\
5. & 31.13 & 33.1 & 0.063 \\
6. & 31.31 & 32.9 & 0.051 \\
7. & 32 & 32.8 & 0.025 \\
8. & 31.81 & 32.1 & 0.009 \\
9. & 31.63 & 32.1 & 0.015 \\
10. & 31.31 & 32.3 & 0.032 \\
\hline \multicolumn{5}{r}{}
\end{tabular}

\section{PEMBAHASAN}

Penelitian mengenai rancang bangun sistem monitoring salinitas dan suhu pada air laut ini terdiri dari rangakaian salinitas dan rangakaian suhu. Rangkaian salinitas menggunakan dua buah kabel tembaga sebagai elektroda yang berfungsi sebagai penghantar arus ke dalam air laut. Air laut merupakan eletrolit kuat yang dapat menghantarkan arus listrik. Arus listrik yang mengalir pada air laut berbanding lurus dengan konduktivitas, sehingga semakin tinggi tingkat salinitas maka nilai konduktivitasnya semakin tinggi. Hal ini menunjukkan kemampuan untuk menghantarkan arus listrik semakin tinggi dan tegangan keluarannya semakin bertambah.

Tabel 2 menunjukkan pengukuran nilai dari tegangan keluaran dan nilai salinometer. Pada tabel tersebut diketahui bahwa nilai tegangan keluaran yang di dapat bertambah ketika nilai salinitasnya semakin tinggi. Di antara titik keenam dan titik ketujuh pada grafik terdapat perbedaan tegangan yang cukup tinggi, hal ini dikarenakan jumlah ion yang bergerak cenderung tidak stabil. Pada Tabel 2 diketahui nilai tegangan terendah ialah 1,135 Volt, yang mana pengukuran ini dilakukan pada pangkal Jembatan Nelayan Berbas Pantai Bontang Selatan. Pada Tabel 2 juga diketahui nilai tegangan tertinggi ialah 1,260 Volt, yang mana pengukuran ini dilakukan pada ujung Jembatan Nelayan Berbas Pantai Bontang Selatan yang berhubungan langsung dengan laut lepas. Rendahnya tingkat salinitas yang ada di pangkal jembatan nelayan disebabkan oleh adanya interaksi masuknya air dari pemukiman warga.

Berdasarkan Tabel 2, diperoleh grafik kaitan antara tegangan keluaran terhadap salinitas yang ditunjukkan oleh Gambar 6. Dari grafik Gambar 6 diperoleh nilai regresi linier rangkaian 
salinitas sebesar $y=21,698 x+4,5407$. Nilai y adalah nilai salinitas pada salinometer dan $x$ adalah nilai tegangan keluaran yang dihasilkan oleh rangkaian salinitas ini. Nilai koefisien regresi linear $\left(R^{2}\right)$ adalah 0,9383 . Sensitivitas dari sistem rangkaian sensor salinitas ini ialah $21,698 \mathrm{~V} / \mathrm{ppt}$. Dan nilai intercept atau titik potong sebesar $+4,5407$. Selanjutnya persamaan linier grafik digunakan untuk merubah nilai tegangan menjadi nilai salinitas.

Dari nilai regresi linier rangkaian salinitas tersebut didapatkan nilai salinitas yang ditunjukkan pada Tabel 3. Tabel 3 menunjukkan nilai tingkat salinitas yang dibaca oleh sistem rancang bangun salinitas yang di buat. Nilai tingkat salinitas yang dibaca oleh sistem ini, kemudian di bandingkan dengan salinometer acuan yaitu Refractometer. Perbandingan ini menggunakan perbandingan tingkat akurasi. Perbandingan tingkat akurasi ini dilakukan untuk mengetahui seberapa jauh hasil pengukuran menggunakan sistem rancang bangun salinitas yang dibuat mendekati hasil sebenarnya yang menggunakan Salinometer Refractometer. Dan dari tabel 3 diketahui rata-rata presentase kesalahan dari rancang bangun salinitas yang di buat adalah 0,0073\%.

Rangkaian suhu ini menggunakan sensor suhu DS18B20 yang berfungsi sebagai pendeksi perubahan suhu pada air laut. Tabel 4 menunjukkan pengukuran nilai dari DS18B20 dan termometer digital. Perubahan suhu permukaan air laut di sebabkan oleh faktor, yaitu cuaca dan intensitas matahari pada saat pengambilan data. Pada saat pengambilan data, keadaan langit yang tidak cerah dan berangin sehingga intensitas matahari rendah yang kurang efektif dalam pemanasan masa air permukaan secara langsung. Hal tersebut menyebabkan suhu permukaan air laut menjadi turun.

Menurut [5], tinggi rendah salinitas sangat bergantung pada penguapan, curah hujan, run off, dan pencairan es di kutub. Intensitas cahaya matahari yang tinggi menyebabkan penguapan yang semakin besar sehingga salinitas akan semakin tinggi, curah hujan yang tinggi menyebabkan salinitas berkuran. Semakin banyaknya aliran air tawar yang masuk ke laut menjadikan salinitas air laut berkurang. Dan berdasarkan penelitian yang dilakukan oleh [3], bahwa nilai salinitas dapat ditentukan dengan penentuan konduktivitas dengan cara pengukuran tegangan. Semakin tinggi salinitas, maka semakin besar nilai tegangan dan semakin besar nilai tegangan, maka semakin besar nilai konduktivitasnya.

Ada beberapa faktor yang mempengaruhi pengukuran oleh sensor dan sistem monitoring yang telah dibuat. Pada pengukuran setiap perubahan tingkat salinitas telah menunjukkan perubahan pada tegangan keluaran yang didapatkan, tetapi masih terdapat selisih pada nilainya. Hal ini dapat disebabkan oleh terjadinya korosi pada katoda yang digunakan dikarenakan adanya aktivitas anion dan kation air laut. Hal tersebut menyebabkan noise pada output sistem. Sistem monitoring yang dapat mengukur nilai tegangan dengan skala Volt juga mengukur noise yang terjadi. Hal ini disebabkan karena pada dasarnya tidak ada alat yang ideal dan selalu terdapat noise pada alat yang telah dibuat.

\section{KESIMPULAN}

Melalui penelitian ini dihasilkan alat instrumentasi salinitas dan temperatur dengan menggunakan elektroda berbahan tembaga dan DS18B20 yang beroperasi pada tegangan 4.8 Volt dan didapatkan grafik linier antara tegangan dan salinitas. Pada penelitian ini, diketahui juga hubungan antara tegangan dan salinitas adalah berbanding lurus. Semakin tinggi nilai salinitas air laut maka tegangan keluaran akan semakin besar. 


\section{UCAPAN TERIMA KASIH}

Penulis mengucapkan terima kasih kepada Bapak Dr. Eng Idris Mandang, M.Si dan dan Ibu Devina Rayzy PSP., M.SC selaku pembimbing yang telah membantu memberikan ide, pemahaman, saran dan masukkan serta waktu sehingga penelitian ini dapat terselesaikan. Orang tua dan temanteman yang telah memberikan dukungan dan menyemangati penulis.

\section{DAFTAR PUSTAKA}

[1] D. M. Siltri, Yohandri and Z. Kamus, "Pembuatan Alat Ukur Salinitas dan Kekeruhan Air Menggunakan Sensor Elektroda dan LDR," Jurnal Sainstek, pp. 126-139, 2015.

[2] N. Melinda and Suryono, "Rancang Bangun Sistem Wirless Sensor Salinitas Model Kapasitif," Youngster Physics Journal, pp. 76-84, 2018.

[3] N. M. Pambudiarto, Rancang Bangun Alat Pengukur Kadar Garam (Salinitas) Berbasis Mikrokntroler AT89S51. Skripsi, Semarang: Universitas Negeri Semarang, 2010.

[4] A. I. Burhanuddin, Biologi Kelautan, Yogyakarta: Lily p, 2019.

[5] w. Prarikeslan, Oseanografi, Jakarta: Kencana, 2016.

[6] P. N. Kalangi, A. Mandagi, K. Masengi, A. Lausunaung, F. Pangalila and M. Iwata, "Sebaran Suhu dan Salinitas di Teluk Manado," Jurnal Perikanan dan Kelautan Tropis, pp. Vol.IX-2, 2013.

[7] O. J. Semampouw, Buku Ajar Kesehatan Masyarakat Pesisir dan Kelautan, Yogyakarta: Deepublish, 2019.

[8] M. R. Siregar, Rancang Bangun Alat Ukur Kadar Garam (Salinitas) dengan Sensor Salinitas Berbasis Mikrokontroler Atmega8. Laporan Projek Akhir, Sumatera Utara: Universitas Sumatera Utara, 2018.

[9] A. B. Akbar, Pengontrolan Suhu Air Menggunakan Sensor DS18B20 Berbasis Arduino Uno. Tugas Akhir, Sumatera Utara: Universitas Sumatera Utara, 2017.

[10] A. Rinaldi, "Implementation ofWireless Sensor Network (WSN) to calculate air pollution index of Samarinda City," IOP Conf. Series: Journal of Physics, vol. 55, no. 5, pp. 15-25, 2019.

[11] A. I. Burhanuddin, Biologi Kelautan, Yogyakarta: Lily Publisher, 2019.

[12] F. T. Kirana and Suryono, "Rancang Bangun Sistem Monitoring Kada Salinitas Air Menggunakan Wirless Sensor System (WSS)," Yougster Physics Journal, pp. 227-234, 2016. 